\title{
Naval Essay, 1912
}

\section{Lieut-Col. A. Leetham}

To cite this article: Lieut-Col. A. Leetham (1911) Naval Essay, 1912, Royal United Services Institution. Journal, 55:406, 1693-1693, DOI: 10.1080/03071841109417836

To link to this article: http://dx.doi.org/10.1080/03071841109417836

曲 Published online: 11 Sep 2009.

Submit your article to this journal

Џll Article views: 3

Q View related articles $₫$ 


\section{Royal United Institution.}

NAVAL ESSAY, 1912.

\section{SUBJECT OF THE ESSAY.}

"What is the War Value of Oversea Commerce? How did it affect our Naval Policy in the past, and how does it in the present day?"

(1) Competitors must be Members of the Institution, or persons eligible to become Members.

(2) The Gold Medal of the Institution will be awarded to the best Essay should the Referees consider it to be of sufficient merit. The "Trench-Gascoigne" prizes are allotted as follows:-Thirty Guineas to the winner of the Gold Medal, and Twenty Guineas to the writer of the Essay next in order of Merit.

(3) The Essays must not exceed 49 pages (exclusive of tables) of the size and style of the Journat, each page averaging 540 words.

(4) When a reference is made to any work, the title of such work to be quoted.

(5) The Essays must be received by the Secretary on or before the lith day of November, 1!1z.

(6) The Essay's must be strictly anonymous, and each must have a Motto and be accompanied by a sealed envelope with the Motto written on the outside and the name of the Candidate inside.

(i) The Essays will be submitted for decision to three Referees, chosen by the Council ; but no award will be made by them in favour of any Essay which does not, in their opinion, attain a sufficient standard of excellence.

(8) The awards of the Referees will be made known, and the Medal presented to the successful Carididate (or his representative) at the Anniversary Meeting, and his Essay will be printed in the Joursal.

(9) All Essays must be typewritten and submitted in triplicate.

(10) The Council trust that unsuccessful Candidates will accept the decision of the Referees in a loyal spirit, and will refrain from comment in the Press or otherwise.

(II) All Essays submitted will become the property of the Council absolutely:

By Order of the Council,

A. LEETHA.1, Lieut.-Col., Sccretery.

Whitemall, Loxdox, S.W.

lst /anuary, 1912. 